\title{
ANAEROBIC DIGESTION OF LANDFILL LEACHATE WITH NATURAL ZEOLITE AND SUGARCANE BAGASSE FLY ASH AS THE MICROBIAL IMMOBILIZATION MEDIA IN PACKED BED REACTOR
}

\author{
Hanifrahmawan Sudibyo ${ }^{a, b}$, Zata Lini Shabrina ${ }^{a}$, \\ Hartika Rafih Wondah ${ }^{a}$, Retno Tri Hastuti ${ }^{a}$, Lenny Halim ${ }^{a}$, \\ Chandra Wahyu Purnomo ${ }^{a}$, Wiratni BudhiJanto ${ }^{a, b, *}$ \\ ${ }^{a}$ Chemical Engineering Department, Faculty of Engineering, Universitas Gadjah Mada, Jalan Grafika No. 2, \\ Yogyakarta 55281, Indonesia \\ ${ }^{b}$ Center for Energy Studies, Universitas Gadjah Mada, Jalan Bhinneka Tunggal Ika Sekip UGM K-1A, \\ Yogyakarta 55281, Indonesia \\ * corresponding author: wiratni@ugm.ac.id
}

\begin{abstract}
To enhance the digestion rate of a landfill leachate in the anaerobic packed bed reactor, a natural zeolite and sugarcane bagasse fly ash (BFA) were tested as the immobilization media. In order to scale up this process and systematically optimize the reactor performance, a kinetics model was needed. The suitability of the Contois and Haldane growth kinetic models were tested on the experiment data. It turned out that Contois gave the best fit for both acidogenic and methanogenic steps. A statistical analysis on Contois kinetic parameters using the Pearson correlation coefficient indicated that, in comparison with the BFA, the zeolite, as an immobilization media, showed more positive effects on the performance of the anaerobic digestion of a leachate.
\end{abstract}

KEYWORDs: landfill leachate, natural zeolite, sugarcane bagasse fly ash, growth kinetics, Contois, Haldane.

\section{INTRODUCTION}

\subsection{LANDFILL LEACHATE PROBLEM IN DEVELOPING COUNTRY}

The increase of the municipal waste accumulation in conventional landfill sites has caused severe environmental impacts. In Indonesia, the high organic fraction in the municipal solid waste leads to an excessive leachate release. The leachate generated from landfill sites usually contains a high amount of organic and inorganic contaminants [1]. The organic and inorganic contaminants in the leachate were commonly characterized by the high values of chemical oxygen demand (COD), $\mathrm{pH}$, ammonia nitrogen and heavy metals and strong colour and bad odour. The removal of an organic material represented by the COD, biochemical oxygen demand (BOD), and ammonium from the leachate is the mandatory prerequisite for discharging the leachates into water bodies [2].

A biological treatment of the leachate was quite complicated due to the excessive amount of it, possible contents toxic to the digesting microbial and the uncertainty of its composition. The leachate composition can vary depending on several factors, including the degree of compaction, waste composition, moisture content in the waste, composition and volume and the age of the landfill [3, 4].Several methods are currently available to treat the landfill leachate. Most of them are adapted for wastewater treatment processing and can be divided into two main categories: biological treatments and physical/chemical treatments [5]. The latter was often chosen over the biological treatment because it was easier and faster. However, it was usually a costlier and energy intensive operation and created other environmental problems due to the chemical release to the water bodies [5].

In a densely populated country like Indonesia, the large landfill site input could be as high as 50006000 ton/day of municipal solid waste (MSW), with a $60-70 \%$ organic fraction. This MSW characteristic produced high amount of a leachate with a high organic content. An anaerobic digestion of this organicrich landfill leachate would potentially produce a significant amount of biogas. Energy generation from the leachate in the form of a biogas makes anaerobic digestion even more attractive to Indonesia, because this country is now heavily relying on imported fossil fuel [6]. The biogas produced in the landfill site could be converted into electricity that could be used for further treatment of the effluent aerobically, using more energy-efficient aeration system [7, 8].

However, the common hindrance to run the anaerobic digestion for the leachate treatment was the slow growth of microorganisms, so the usage of a conventional anaerobic digester required a huge volume of the digester [9]. Besides, a wash out often happened at the conventional anaerobic digester, especially for 
a high flow rate feed. The solution for stabilizing and maximizing the microbial growth is immobilizing the cell on solid media [9, 10. The cell immobilization on solid media can be defined as a localization of an intact cell via a physical adsorption between the carrier and cell membrane [11]. The microbial immobilization can be applied in various designs of reactors, such as the fixed bed, fluidized bed, or the membrane reactor to minimize the possibility of the cell to be washed out.

\subsection{MATERIAL OF THE IMMOBILIZATION MEDIA}

The natural zeolite and sugarcane bagasse fly ash (BFA), which are both widely and abundantly available in Indonesia, have a potential to be used as an immobilization media. As an inorganic material, the natural zeolite is able to immobilize the biological species through offering interesting characteristics, such as mechanical and chemical resistance and a high surface area. It has the advantage of the mineral content, such as silica and alumina (the major component) [12 calcium, magnesium, etc., which could enhance the cell growth. Zeolites are also known to be stable both in wet and dry conditions and well-tolerated by microorganisms, and therefore, normally compatible with a bioprocess application.

The sugarcane bagasse, a residue obtained after crushing the sugarcane to extract the broth, was the most abundant lignocellulosic residue, with 1-1.2 ton of bagasse produced for 10 tons of sugarcane consumed for a sugar production [13]. Although most of the bagasse had been used in the sugarcane industry itself to generate energy, there was a surplus of this agro-industrial residue and several alternatives for its utilization had been evaluated, among which was the production of vanillin [14] and xylitol [15, 16]. In this respect, the sugarcane bagasse has already been used with promising results as a cell support in different bioprocesses [17].

The performance of both the BFA and the natural zeolite as the immobilization media in the landfill leachate anaerobic digestion was evaluated in this work. The comparison was conducted quantitatively by means of a mathematical model to compare the kinetics parameter between the process using a natural zeolite and the process using the BFA. The appropriate growth kinetics model was chosen based on the best fit of the experimental data indicated by the minimum sum of squares of errors (SSE). The Pearson correlation coefficient was selected as the statistical tool to verify the correlation between the additions of the immobilization media to the digester performance represented by the kinetics parameters. Furthermore, the mathematical model suggested in this paper could be very useful in the future for scaling up and optimizing the design of the full scale reactors.

\subsection{Kinetic MOdel of ANAERobic DIGESTION WITH IMMOBILIZED MICROBES}

In digesting the leachate, there are two processes that must be carried out - acidogenesis and methanogenesis. Currently, there are two suitable models for describing the leachate or wastewater digestion - Contois kinetics [18] and Haldane kinetics [19]. On the one hand, the Contois kinetics has been proven to describe the acidogenesis step well, especially with the substrate type like wastewater and leachate [18. On the other hand, for the methanogenesis step, there are still some discussions about the most suitable model due to some existing phenomenon. After the acidogenesis begins and starts producing a volatile fatty acid (VFA), this VFA usually inhibits the microorganism growth, this is known as the substrate inhibition. That is why using Contois kinetics for the methanogenesis is not sometimes suitable to describe the phenomenon well. Fortunately, the Brigg-Haldane kinetics accommodates the substrate inhibition phenomenon. Therefore, it was necessary to compare which model suited better to describe the mechanism of the anaerobic leachate digestion, especially for the methanogenesis step. To do so, an anaerobic batch digestion inside the packed-bed reactor would be conducted to obtain the necessary data for the kinetics study. This kinetics study would be beneficial for optimizing the performance of the continuous anaerobic packed-bed reactor.

According to the aforementioned explanation, there were two scenarios that could be set up to find the mechanism of the anaerobic leachate digestion. The first scenario consisted of the acidogenesis step, which was described by the Contois kinetics, and followed by the methanogenesis step, which was described by the Haldane kinetics. The other scenario consisted of acidogenesis and methanogenesis steps, which were only described by the Contois kinetics. A set of differential equations was derived from both scenarios. The first scenario's set of differential equations consists of (1), (2), (4), (5), and (6), whereas the second scenario's set of differential equations consists of (1) (3) (4) (5), and (6), where

$$
\begin{aligned}
\frac{\mathrm{d} X_{1}}{\mathrm{~d} t} & =\frac{\mu_{\mathrm{m} 1} s_{\mathrm{COD}} X_{1}}{K_{\mathrm{SX} 1} X 1+s_{\mathrm{COD}}}-k_{\mathrm{d} 1} X_{1}^{c_{1}} \\
\frac{\mathrm{d} X_{2}}{\mathrm{~d} t} & =\frac{\mu_{\mathrm{m} 2} C_{\mathrm{VFA}} X_{2}}{K_{\mathrm{SX} 1} X_{2}+C_{\mathrm{VFA}}+C_{\mathrm{VFA}}^{2} / K_{\mathrm{I}}}-k_{\mathrm{d} 2} X_{2}^{c_{2}} \\
\frac{\mathrm{d} X_{2}}{\mathrm{~d} t} & =\frac{\mu_{\mathrm{m} 2} C_{\mathrm{VFA}} X_{2}}{K_{\mathrm{SX} 1} X_{2}+C_{\mathrm{VFA}}}-k_{\mathrm{d} 2} X_{2}^{c_{2}} \\
\frac{\mathrm{d} s_{\mathrm{COD}}}{\mathrm{d} t} & =\frac{1}{Y_{\mathrm{X} 1 / \mathrm{COD}}} \frac{\mathrm{d} X_{1}}{\mathrm{~d} t} \\
\frac{\mathrm{d} C_{\mathrm{VFA}}}{\mathrm{d} t} & =Y_{\mathrm{VFA} / \mathrm{X} 1} \frac{\mathrm{d} X_{1}}{\mathrm{~d} t}-\frac{1}{Y_{\mathrm{X} 2 / \mathrm{VFA}}} \frac{\mathrm{d} X_{2}}{\mathrm{~d} t} \\
\frac{\mathrm{d} C_{\mathrm{CH} 4}}{\mathrm{~d} t} & =Y_{\mathrm{CH} 4 / \mathrm{X} 2} \frac{\mathrm{d} X_{2}}{\mathrm{~d} t}
\end{aligned}
$$

These differential equations are solved numerically 
and the corresponding kinetics constants could be determined by minimizing the Sum of Square of Error (SSE) between the calculated and experimental data of the organic matter concentration as the acidogenic cell $\left(X_{1}\right)$, methanogenic cell $\left(X_{2}\right)$, substrate $\left(s_{\mathrm{COD}}\right)$, volatile fatty acid $\left(C_{\mathrm{VFA}}\right)$, and methane $\left(C_{\mathrm{CH} 4}\right)$.

Afterwards, the change of kinetics constants related to the additions of more immobilization media would be verified through the Pearson correlation coefficient:

$$
r=\frac{n \sum x y-\sum x \sum y}{\sqrt{\left(n \sum x^{2}-\left(\sum x\right)^{2}\right)\left(n \sum y^{2}-\left(\sum y\right)^{2}\right)}} .
$$

The calculated correlation coefficient was transformed into absolute value and then compared with the critical value of the Pearson correlation coefficient. The absolute value of the calculated correlation coefficient must be greater than the critical value to show that there is a correlation. After being verified that there was a correlation, the integer value of the correlation coefficient (either positive or negative) shows what the correlation was. The interpretation would be linearly correlated, inversely correlated, or not correlated at all.

\section{Materials And Methods}

\subsection{MATERIALS}

A fresh leachate was obtained from Piyungan Sanitary Landfill, Yogyakarta, Indonesia. Starter, in the form of an active digester effluent, was supplied by the cow-manure-based biogas mini-plant located at Gadjah Mada University's PIAT (Pusat Inovasi Agroteknologi) at Berbah, Sleman. The immobilization media was produced from the Lampung natural zeolite and PT. Madukismo sugarcane bagasse fly ash, which were supported by bentonite as the adhesive agent. High purity chemicals were used in this work for analytical routines, which included $\mathrm{H}_{2} \mathrm{SO}_{4}$ $98 \%$ (Merck), $\mathrm{HCl} 37 \%$ (Merck), $\mathrm{NaOH}$ (Merck), $\mathrm{C}_{8} \mathrm{H}_{5} \mathrm{KO}_{4}$ p.a. (EMSURE), $\mathrm{HgSO}_{4}$ p.a. (EMSURE), $\mathrm{AgSO}_{4}$ p.a. (Merck), $\mathrm{K}_{2} \mathrm{Cr}_{2} \mathrm{O}_{7}$ p.a. (EMSURE), $\mathrm{Na}_{2} \mathrm{~B}_{4} \mathrm{O}_{7} \cdot 10 \mathrm{H}_{2} \mathrm{O} 99.55 \%$ (Merck), and $\mathrm{CH}_{3} \mathrm{COOH}$ $96 \%$ p.a. (Merck).

\subsection{Production of Immobilization Media From Natural ZeOLITE}

The BFA and the raw natural zeolite powder (undersize 100 mesh) were each mixed with bentonite with the mass ratio of $1: 1$. Afterwards, the mixture was moulded to form the Raschig ring with the size of $1 \mathrm{~cm}$ inside diameter, $5 \mathrm{~mm}$ thickness, and $2 \mathrm{~cm}$ long by the extruder. Lastly, the moulded mixture was kept heated at $110^{\circ}$ for 12 hours by using the furnace Thermolyne Tube Heater Type F21100.

\subsection{Anaerobic Digestion of Leachate}

The anaerobic digestion was operated in a batch system using a vertical-cylinder-formed digester made of

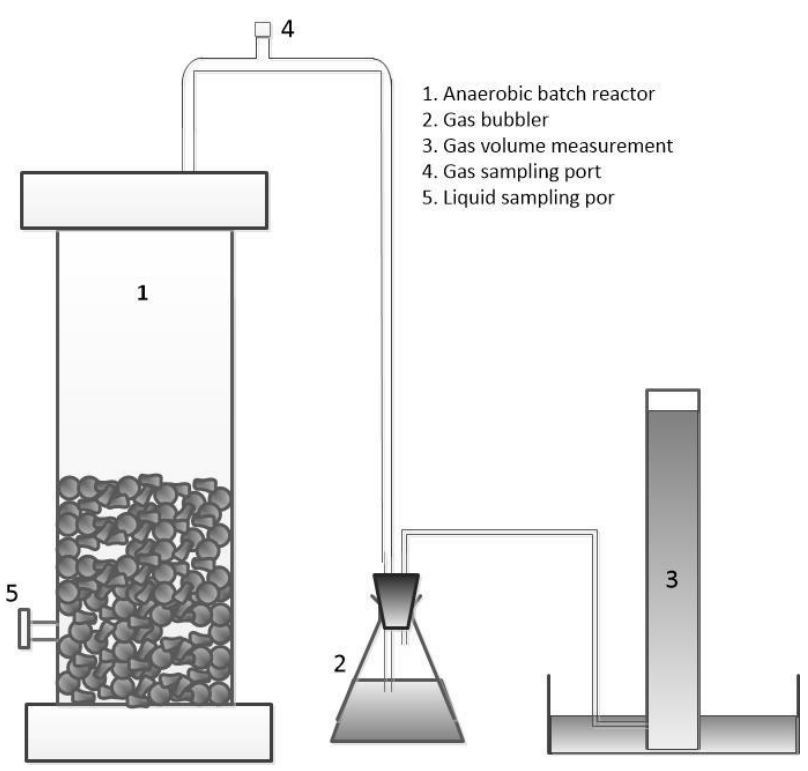

FiguRE 1. Experimental set-up.

\begin{tabular}{lcc}
\hline Month & \multicolumn{2}{c}{ Parameter } \\
\cline { 2 - 3 } & sCOD, mg/L & VFA, mg/L \\
\hline 1 & 3660 & 1132 \\
2 & 5895 & 1220 \\
3 & 2620 & 970 \\
\hline
\end{tabular}

TABLE 1. Leachate characteristics over three different months in 2016 .

acrylic and equipped with a vertical tube gasometer (Figure 1). In this work, the digester volume was $3 \mathrm{~L}$ with the L/D ratio of 4.6. The fresh leachate was fed to the digester without any dilution so that the initial concentration of the leachate (in the form of sCOD) would be different for each experiment batch. The sCOD and VFA concentration analysis, identifying the initial leachate characteristics, resulted in the data shown in Table 1. The difference was caused mostly by rainfall.

To identify the effect of the immobilization media addition to the digester performance, the number of the immobilization media varied. Since both immobilization media had different bulk density, the number of the immobilization media was calculated based on the volume fraction inside the digester. Because of the same basic area, the immobilization media would be $1 / 4,1 / 2$, and $3 / 4$ of the digester height. Through this way, the zeolite ratios were $150 \mathrm{~g} / \mathrm{g}$ sCOD, $240 \mathrm{~g} / \mathrm{g} \mathrm{sCOD}$, and $350 \mathrm{~g} / \mathrm{g} \mathrm{sCOD}$, while the BFA ratios were $43 \mathrm{~g} / \mathrm{g} \mathrm{sCOD}, 110 \mathrm{~g} / \mathrm{g}$ sCOD, and $164 \mathrm{~g} / \mathrm{gsCOD}$. The anaerobic digestion without immobilization media was set as the control ( $0 \mathrm{~g}$ zeolite/g sCOD) and was executed for each immobilization media. 


\subsection{Analytical method of SCOD, VFA, $\mathrm{CH}_{4}$, AND MICROBIAL CONCENTRATION}

The quantification of the microbes in the digester was conducted using the heterotrophic plate counts method explained by Boothe et al. [20] and by APHA [21]. Obtained number of the cell (in cell/L) was then converted into a mass concentration $(\mathrm{g} / \mathrm{mL})$ by multiplying with the mass of a cell $(1.15 \mathrm{pg} / \mathrm{cell})$ 22. The mass concentration of the acidogenic and the methanogenic microbes was estimated by using the ratio of $9: 1$ (acidogenic : methanogenic microbes) [23]. The calculation is as follows:

$$
\begin{aligned}
& X_{1}\left[\frac{\mathrm{mg}}{\mathrm{L}}\right]=0.9\left(\# \text { of cells }\left[\frac{\mathrm{cell}}{\mathrm{mL}}\right] 1.15 \frac{\mathrm{pg}}{\text { cell }} 10^{6} \frac{\mathrm{mg}}{\mathrm{pg}} \frac{\mathrm{mL}}{\mathrm{L}}\right), \\
& X_{2}\left[\frac{\mathrm{mg}}{\mathrm{L}}\right]=0.1\left(\# \text { of cells }\left[\frac{\mathrm{cell}}{\mathrm{mL}}\right] 1.15 \frac{\mathrm{pg}}{\text { cell }} 10^{6} \frac{\mathrm{mg}}{\mathrm{pg}} \frac{\mathrm{mL}}{\mathrm{L}}\right) .
\end{aligned}
$$

In this work, the variable used to represent the substrate concentration was the soluble COD (sCOD). The analysis of the sCOD, VFA, and ammonia during the experiment would follow the standard procedure by the APHA [24]. The sCOD analysis was conducted as the closed reflux colorimetric method. The VFA analysis used the titrimetric method and the ammonia measurement used the ion selective electrode (ISE) measurement. The gas volume was measured using the gasometer method outlined by Walker [25] while the methane content was analysed by using the Gas Chromatography (GC) Shimadzu GC 8A. The data of the methane production was presented using $\mathrm{mL} / \mathrm{g} \mathrm{sCOD}$ (removed) unit $[26$ and in a volume percentage to describe its purity.

\section{Results And Discussion}

\subsection{ACIDogenic And Methanogenic CELL GROWTH BEHAVIOR}

According to the experimental data (Figure 2), both for the acidogenic cell $\left(X_{1}\right)$ and the methanogenic cell $\left(X_{2}\right)$, it could be seen that each growth phase ran for the same period of time when the natural zeolite and BFA were used as the immobilization media. For instance, the lag phase ran for the same period of time before and after the addition of the immobilization media (from day 0 to day 7 ). From day 7 to day 13, the slope was increasing sharply, so it could be considered as the beginning of the log phase. Between the day 13 and 35, the slope started declining, so it could be assumed that the stationary phase began at this period. However, the maximum concentration of the cell was the differentiator. For instance, with the increase of the number of the immobilization media, the maximum concentration of the cell reached during the lag phase was greater than the one without using immobilization media. The maximum concentration increased largely when the immobilization media filled $3 / 4$ of the digester volume.

\subsection{SCOD AND $C_{\mathrm{VFA}}$ PROFILE}

As the consequence of the cell growth, four parameters experienced changes - the sCOD, $C_{\mathrm{VFA}}$, cumulative

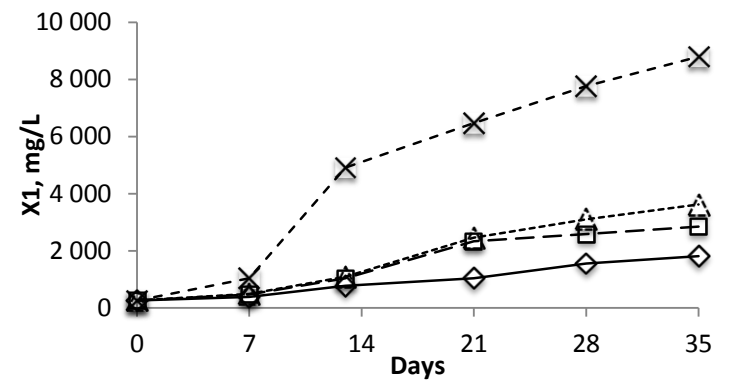

(a)

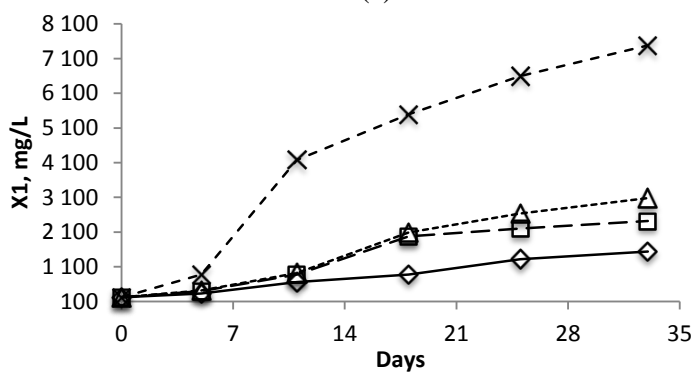

(b)

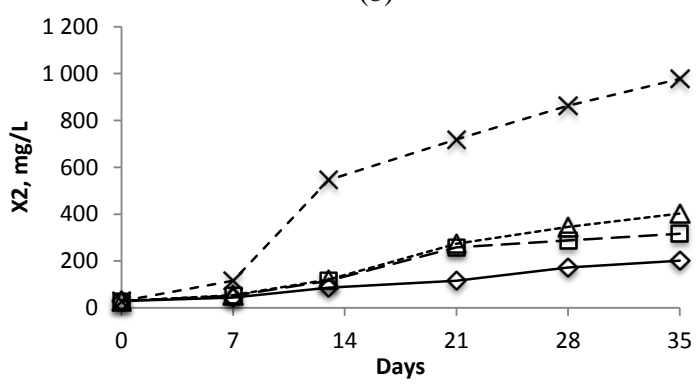

(c)

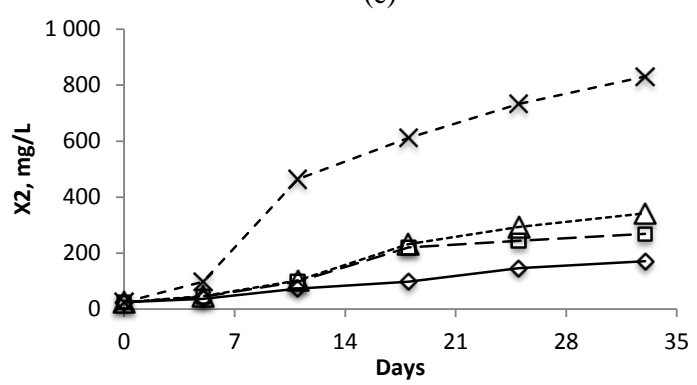

(d)

Figure 2. Concentration of acidogenic cell $\left(X_{1}\right)$ and methanogenic cell $\left(X_{2}\right)$ in leachate during anaerobic digestion: (a) $X_{1}$-zeolite; (b) $X_{1}$-BFA; (c) $X_{2}$-zeolite; (d) $X_{2}$-BFA (diamonds - no media; triangles - $1 / 4$ height of digester; squares $-1 / 2$ height of digester; crosses $-3 / 4$ height of digester).

methane purity $\left(\% \mathrm{CH}_{4}\right)$, and cumulative methane production. In the digester immobilized with the zeolite, the sCOD and $C_{\mathrm{VFA}}$ decreased consistently in time (Figure 3ac). This consistent decrease stood in line with the growth characteristic of the acidogenic cell (Figure 2a), which increased in time. However, the fastest significant sCOD decrease occurred in the digesters, which were immobilized by the natural zeolite by as many as $1 / 2$ and $3 / 4$ of the digester volume $(240 \mathrm{~g} / \mathrm{g} \mathrm{sCOD}$ and $350 \mathrm{~g} / \mathrm{g} \mathrm{sCOD})$. In those digesters, the sCOD decreased significantly from the day 7 to 13 


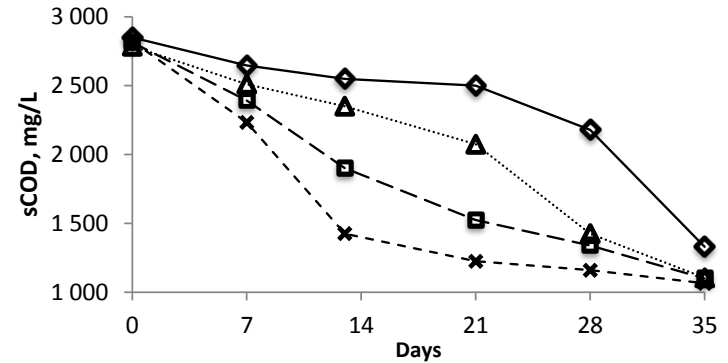

(a)

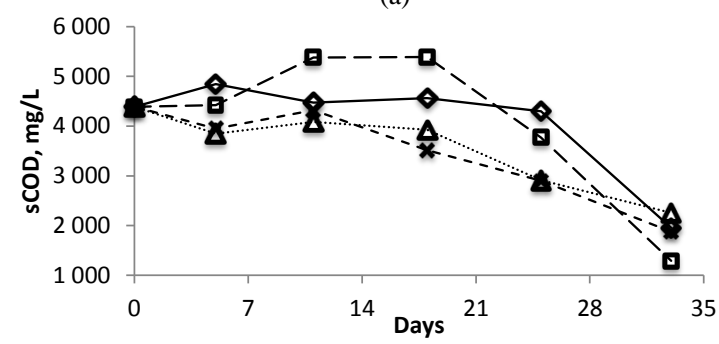

(b)

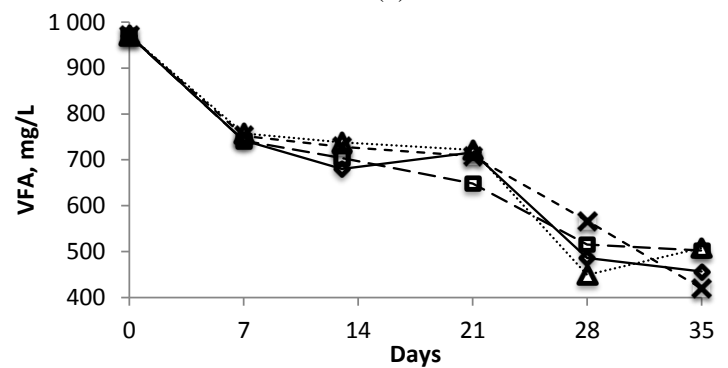

(c)

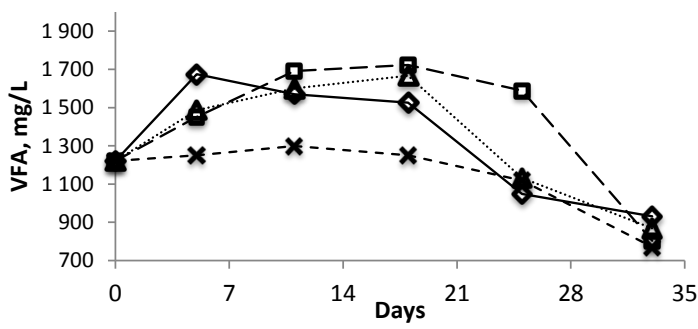

(d)

Figure 3 . sCOD and $C_{\mathrm{VFA}}$ profile during anaerobic digestion: (a) sCOD-zeolite; (b) sCOD-BFA; (c) VFA-zeolite; (d) VFA-BFA (diamonds - no media; triangles $-1 / 4$ height of digester; squares $-1 / 2$ height of digester; crosses - 3/4 height of digester).

(shown by a steeper slope). Meanwhile, the digester without any immobilization media and the digester with the immobilization by the natural zeolite by as much as $1 / 4$ of digester volume had a significant but late sCOD decrease from the day 21 to 35 . Therefore, the addition of the zeolite seemed to be influential to the rate of the sCOD consumption by the cell after the zeolite ratio was greater than $110 \mathrm{~g} / \mathrm{g} \mathrm{sCOD}$.

However, the digester immobilized by the BFA had both the sCOD and the $C_{\mathrm{VFA}}$ increasing from the day 0 to 21 (Figure 3ed). This phenomenon could possibly be explained as the degradation (through hydrolysis) of the insoluble compound, such as complex carbohydrates and proteins in form of particulate, into the simple ones, which were soluble. Thus, the sCOD could increase, because the sCOD increase

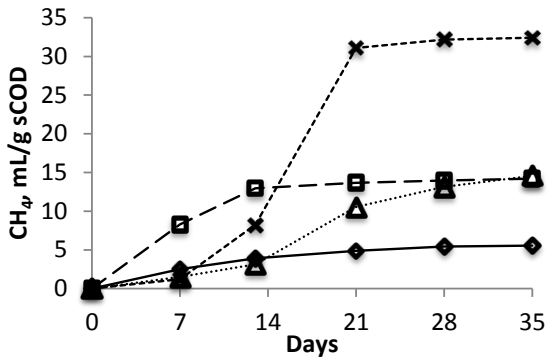

(a)

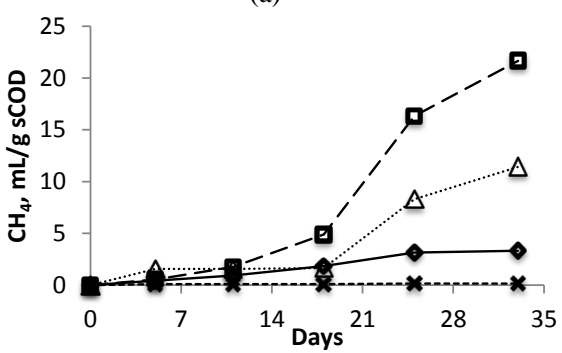

(b)

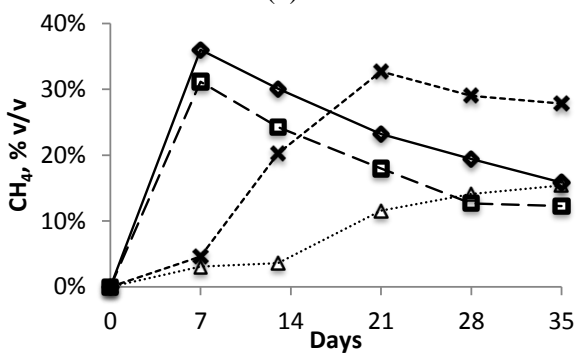

(c)

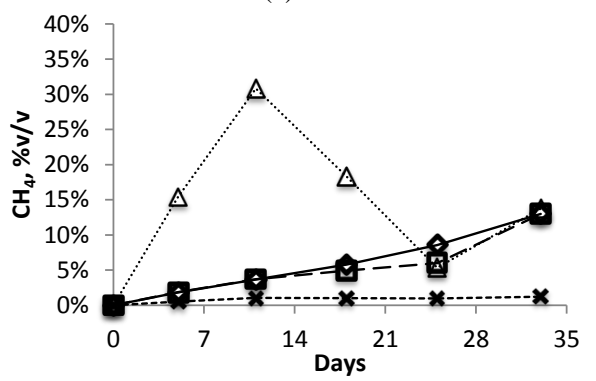

(d)

Figure 4. Cumulative methane production and methane percentage $\left(\% \mathrm{CH}_{4}\right)$ profile during anaerobic digestion: (a) $\mathrm{CH}_{4}$-zeolite; (b) $\mathrm{CH}_{4}$-BFA; (c) $\% \mathrm{CH}_{4}$-zeolite; (d) \% $\mathrm{CH}_{4}$-BFA (diamonds - no media; triangles $-1 / 4$ height of digester; squares $-1 / 2$ height of digester; crosses $-3 / 4$ height of digester).

caused by the hydrolysis was greater than the $\mathrm{sCOD}$ decrease caused by the acidogenic cell consumption. After the day 21, the sCOD started decreasing, which means that the insoluble compounds had completely degraded into the simple and soluble compounds.

\subsection{Cumulative volume of Biogas and METHANE CONTENT}

The cumulative volume of methane produced from the digester immobilized either by the natural zeolite or by the BFA increased along the time and tended to be stable (reach the asymptote point) at the stationary phase (see Figure $4 \mathrm{ab}$ ). However, the digesters immo- 


\begin{tabular}{lrrrr}
\hline Variable & No media & $\mathbf{1 / 4}$ & $\mathbf{1 / 2}$ & $\mathbf{3 / 4}$ \\
\hline \multicolumn{5}{c}{ Contois-Haldane } \\
\hline$X_{1}$ & 1168700 & 126620 & 141820 & 837480 \\
$X_{2}$ & 677380 & 100750 & 226880 & 1719100 \\
$s_{\mathrm{COD}}$ & 5084200 & 2987200 & 752470 & 951060 \\
$C_{\mathrm{VFA}}$ & 52551 & 187090 & 37764 & 15562 \\
$C_{\mathrm{CH} 4}$ & 110.24 & 43.62 & 12.8 & 0.01 \\
\hline \multicolumn{5}{c}{ Contois-Contois } \\
\hline$X_{1}$ & 8138 & 101610 & 72256 & 280810 \\
$X_{2}$ & 7117 & 62042 & 60491 & 161210 \\
$s_{\mathrm{COD}}$ & 3240500 & 2604100 & 561560 & 1321900 \\
$C_{\mathrm{VFA}}$ & 60428 & 89010 & 29270 & 59133 \\
$C_{\mathrm{CH} 4}$ & 0.47 & 45.95 & 12.15 & 0.01 \\
\hline \multicolumn{5}{c}{}
\end{tabular}

TABLE 2. Comparison of SSE results of two proposed models.

\begin{tabular}{lccrr}
\hline Variable & No media & $\mathbf{1 / 4}$ & $\mathbf{1 / 2}$ & $\mathbf{3 / 4}$ \\
\hline \multicolumn{5}{c}{ Contois-Haldane } \\
\hline$X_{1}$ & 42534 & 252370 & 143390 & 1745400 \\
$X_{2}$ & 13440 & 63460 & 351560 & 1140600 \\
$s_{\mathrm{COD}}$ & 411590 & 17974 & 208410 & 232730 \\
$C_{\mathrm{VFA}}$ & 78732 & 53479 & 68476 & 28177 \\
$C_{\mathrm{CH} 4}$ & 12.07 & 129.41 & 10.57 & 280.21 \\
\hline \multicolumn{5}{c}{ Contois-Contois } \\
\hline$X_{1}$ & 12788 & 28870 & 11343 & 481880 \\
$X_{2}$ & 4344 & 25903 & 8244 & 265090 \\
$s_{\mathrm{COD}}$ & 230980 & 174150 & 105620 & 257410 \\
$C_{\mathrm{VFA}}$ & 19792 & 17427 & 26633 & 27526 \\
$C_{\mathrm{CH} 4}$ & 9.54 & 79.21 & 2.67 & 113.48 \\
\hline
\end{tabular}

TABLE 3. Comparison of SSE results of anaerobic leachate digestion using sugarcane bagasse fly ash as the immobilization media.

bilized by the BFA by more than $1 / 2$ of the digester volume were unfortunately unable to produce more methane. Thus, in this work, the optimum number of the BFA to have a large cumulative volume of methane was $1 / 2$ of digester volume $(101 \mathrm{~g} / \mathrm{g}$ sCOD). Different from the BFA, the more natural zeolite could increase the cumulative volume of the methane produced.

With respect to the methane content, the digester immobilized by the natural zeolite and the one immobilized by the BFA had different methane content profile. The methane content of the zeolite-immobilized digester had specific trend line in which a lower volume of a higher-purity methane was produced during the lag phase and the log phase. Afterward, during the stationary phase, the methane purity decreased and tended to be stable (see Figure 44). The highest stable methane content was reached when the natural zeolite filled $3 / 4$ of the digester volume. The lower number of the natural zeolite only produced methane purity in the range of $12-15 \%$ at a stable conditions.

When the digesters were immobilized by the BFA, the maximum methane content reached at a stable conditions was about $14 \%$ (see Figure $4 \mathrm{~d}$ ). The increase of the methane content tended to be similar among the growth period (lag phase, log phase, and stationary phase). When the number of the BFA inside the digester was increased to $3 / 4$ of the digester volume (164 g/g sCOD), the digester became unproductive in terms of the biogas production rate and methane content. To understand this phenomenon, kinetic study was conducted on the aforementioned data.

\subsection{KINETIC STUDY}

Generally, the SSE results of sCOD, $C_{\mathrm{VFA}}$, and $C_{\mathrm{CH} 4}$ depicted the same performance of both scenarios to fit the experimental data (see Tables 2 and 3 . For each number of the immobilization media both for the natural zeolite and the BFA, the SSE result stayed in the same order of magnitude. For instance, when the digester was immobilized by the natural zeolite by as many as $1 / 2$ of the digester volume, the SSE result of the $\mathrm{SCOD}$ was at a hundred thousand order of magnitude. Although the SSE had a gap about two 


\begin{tabular}{lccrc}
\hline Constants & No med. & $\mathbf{1 / 4}$ & $\mathbf{1 / 2}$ & $\mathbf{3 / 4}$ \\
\hline \multicolumn{5}{c}{ Natural zeolite amount } \\
\hline$\mu_{\mathrm{m} 1}$ & 1.1989 & 1.2028 & 0.8779 & 2.5125 \\
$\mu_{\mathrm{m} 2}$ & 1.1782 & 0.9671 & 0.8564 & 1.2192 \\
$K_{\mathrm{SX} 1}$ & 69.5063 & 18.3186 & 11.8596 & 8.9268 \\
$K_{\mathrm{SX} 2}$ & 25.0034 & 8.2281 & 8.0195 & 2.824 \\
\hline$Y_{\mathrm{X} 1 / \mathrm{COD}}$ & 1.1205 & 1.1066 & 1.5885 & 2.9432 \\
$Y_{\mathrm{X} 2 / \mathrm{VFA}}$ & 0.464 & 2.4561 & 0.5124 & 5.9081 \\
$Y_{\mathrm{CH} 4 / \mathrm{X} 2}$ & 15.7046 & 18.2752 & 16.8141 & 16.476 \\
$Y_{\mathrm{VFA} / \mathrm{X} 1}$ & 0.9845 & 0.0134 & 1.1001 & 0.0283 \\
\hline$k_{\mathrm{d} 1}$ & $4 \cdot 10^{-6}$ & 3.1014 & 2.6587 & 10.5556 \\
$c_{1}$ & 0.3601 & 0.3599 & 0.3613 & 0.3589 \\
$k_{\mathrm{d} 2}$ & 0.0281 & 0.103 & 0.0386 & 0.1899 \\
$c_{2}$ & 0.8321 & 0.8301 & 0.8311 & 0.8278 \\
\hline
\end{tabular}

TABle 4. Kinetics constants of Contois-Contois scenario (second scenario) for natural zeolite as the immobilization media.

\begin{tabular}{lrrrl}
\hline Constants & No med. & $\mathbf{1 / 4}$ & $\mathbf{1 / 2}$ & $\mathbf{3 / 4}$ \\
\hline \multicolumn{5}{c}{ BFA amount } \\
\hline$\mu_{\mathrm{m} 1}$ & 0.1709 & 0.2847 & 0.3766 & 0.6775 \\
$\mu_{\mathrm{m} 2}$ & 0.1222 & 0.2746 & 0.3655 & 0.6695 \\
$K_{\mathrm{SX} 1}$ & 14.6413 & 5.6303 & 2.7611 & 4.1738 \\
$K_{\mathrm{SX} 2}$ & 2.7716 & 9.0647 & 0.4556 & 2.8435 \\
\hline$Y_{\mathrm{X} 1 / \mathrm{COD}}$ & 0.7595 & 0.8443 & 1.1089 & 2.7326 \\
$Y_{\mathrm{X} 2 / \mathrm{VFA}}$ & 0.0663 & 0.1116 & 0.1856 & 0.1587 \\
$Y_{\mathrm{CH} 4 / \mathrm{X} 2}$ & 16.4151 & 50.1092 & 23.6147 & 0.144 \\
$Y_{\mathrm{VFA} / \mathrm{X} 1}$ & 9.9998 & 6.0225 & 3.552 & 4.1674 \\
\hline$k_{\mathrm{d} 1}$ & $3 \cdot 10^{-6}$ & 0.2414 & 0.6659 & 0.5249 \\
$c_{1}$ & 0.0092 & 0.7588 & 0.7588 & 0.7588 \\
$k_{\mathrm{d} 2}$ & 0.1182 & $3 \cdot 10^{-8}$ & 0.2997 & 0.0735 \\
$c_{2}$ & 0.5788 & 0.9571 & 0.9521 & 0.9571 \\
\hline
\end{tabular}

TABlE 5. Kinetics constants of Contois-Contois scenario (second scenario) for BFA as the immobilization media.

\begin{tabular}{lcl}
\hline Constants & In this study & \multicolumn{1}{c}{ Previous studies } \\
\hline$\mu_{\mathrm{m} 1}$ & $0.17-0.25$ & $0.315[27,0.156[28]$ \\
$\mu_{\mathrm{m} 2}$ & $0.12-1.22$ & $0.271[29], 1.2[28]$ \\
$K_{\mathrm{SX} 1}$ & $2.76-69.51$ & $126.32[27], 0.983[29], 20-50[28]$ \\
$K_{\mathrm{SX} 2}$ & $0.46-25.00$ & $151.32[29], 0.4[30], 20-50[28]$ \\
\hline$Y_{\mathrm{X} 1 / \mathrm{COD}}$ & $0.76-2.94$ & $0.82[30]$ \\
$Y_{\mathrm{X} 2 / \mathrm{VFA}}$ & $0.07-5.91$ & $0.983[30]$ \\
$Y_{\mathrm{CH} 4 / \mathrm{X} 2}$ & $0.14-50.11$ & $0.27[30], 11-25[31], 74[32]$ \\
$Y_{\mathrm{VFA} / \mathrm{X} 1}$ & $0.01-10.00$ & $0.4[33]$ \\
\hline$k_{\mathrm{d} 1}$ & $4 \cdot 10^{-6}-10.56$ & $0.48[30]$ \\
$c_{1}$ & $0.01-0.36$ & - \\
$k_{\mathrm{d} 2}$ & $3 \cdot 10^{-8}-0.30$ & $0.48[30]$ \\
$c_{2}$ & $0.58-0.96$ & - \\
\hline
\end{tabular}

TABLE 6. Comparison of the obtained parameters with previous studies.

hundred thousand, it was considered as a small gap due to the SSE concept. When there were six data for a one experiment condition, the SSE would be about 33000 in average. According to the SSE concept, this average meant that there was a difference of only 180 between each experimental data and each calculation result.

Differently, the SSE result of $X_{1}$ and $X_{2}$ depicted that the anaerobic leachate digestion in the zeoliteimmobilized and the BFA-immobilized digester were well described using the Contois model for both the acidogenesis and methanogenesis steps. The comparisons between the $X_{1}$ 's and $X_{2}$ 's SSE of each scenario showed that there was a huge difference because of the different order of magnitude (see Tables 2 and 3 ). For instance, when the digester was immobilized by the BFA by as many as $3 / 4$ of the digester volume, the second scenario had the SSE at a hundred thousand order of magnitude while the first scenario had the
SSE at a million order of magnitude (see Tables 2 and 3). Visually observed, the huge difference of the SSE was caused by the inability of the first scenario (Contois-Haldane models) to fit the experimental data. It clearly revealed that by using the Contois model for both steps, each growth phase, such as lag phase, log phase and the beginning of the stationary phase, was well depicted (see Figures 5 and 6). The kinetics constants value for Contois-Contois scenario, resulted from the numerical calculation using MATLAB, was shown on Tables 4 and 5 .

Compared with previous studies focusing on finding the kinetics of an anaerobic digestion of organic or food waste, the obtained parameters only showed a slight difference. In Table 6, there were two parameters, which cannot be compared with the previous studies since in this work, the death rate equations opened the possibilities of the non-elementary kinetics model (not on the first order) together with proving if it was 


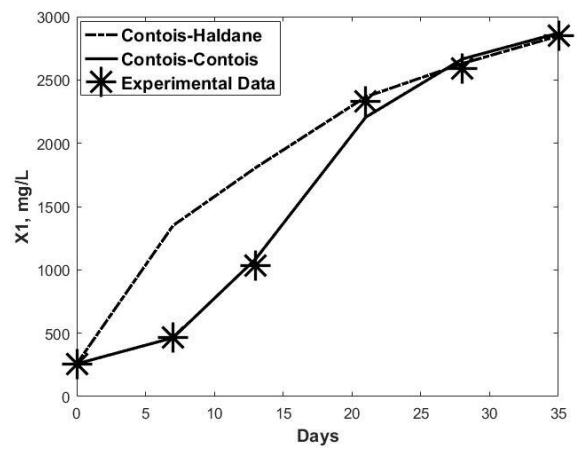

(a) Zeolite - $1 / 4$

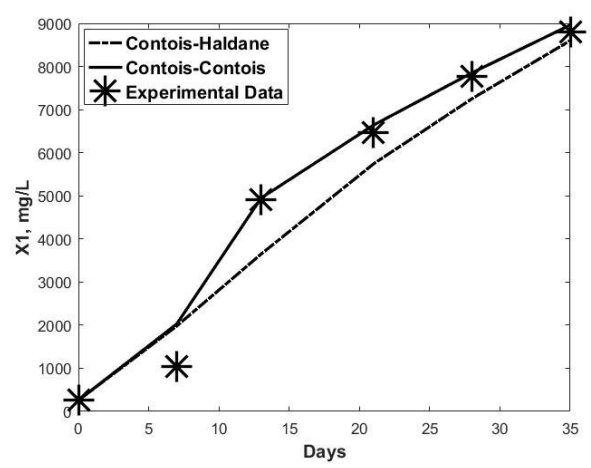

(c) Zeolite - 3/4

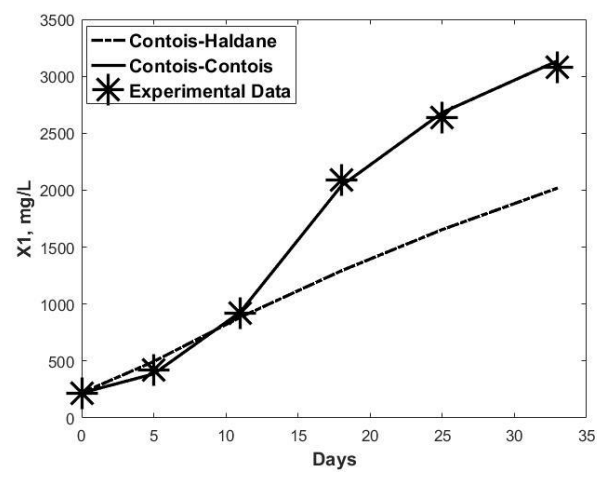

(e) BFA- $1 / 2$

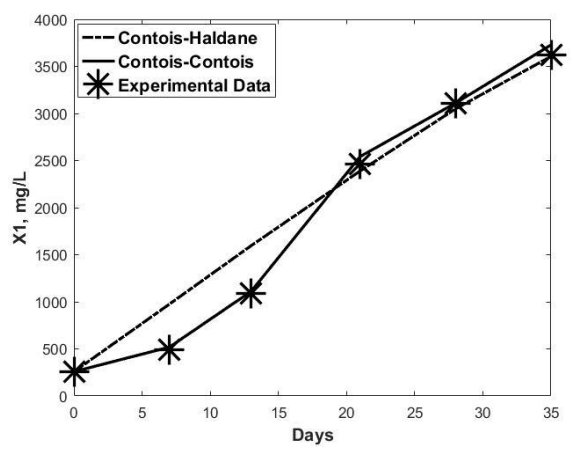

(b) Zeolite - $1 / 2$

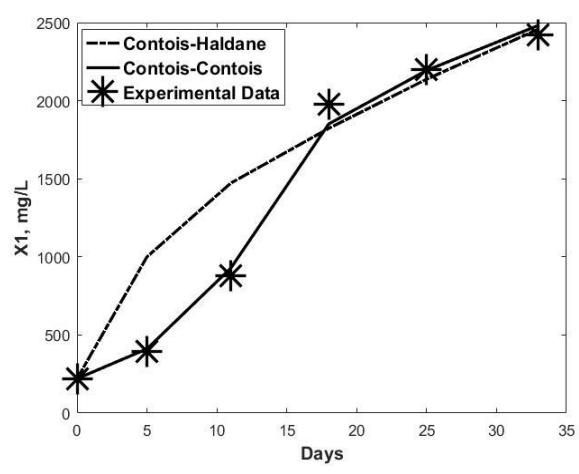

(d) BFA- $1 / 4$

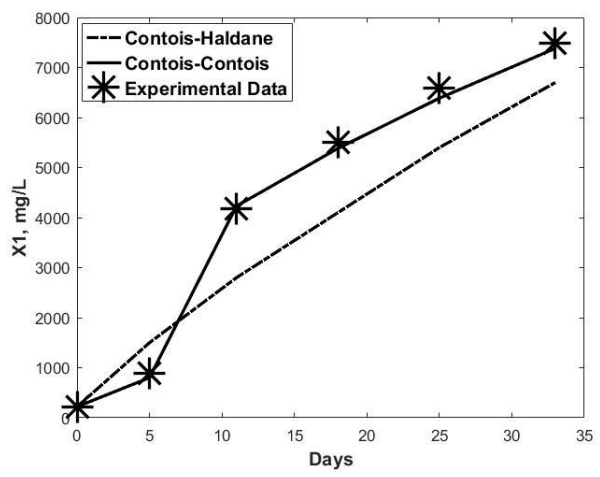

(f) BFA- $3 / 4$

FigURE 5. MATLAB calculation result for acidogenic cell (X1) inside the digester using natural zeolite and BFA as immobilization media.

true that the first order was applicable in this study.

To identify the effect of the increase of the immobilization media number, a statistical approach was used. According to the correlation coefficient result for the experimental data of the zeolite-immobilized digester, the most absolute values of the correlation coefficient were not greater than its critical value. The critical value set in this work was 0.951 , gained from a level of significance of 0.05 and a degree of freedom of 2 . Therefore, statistically, it revealed that the addition of more natural zeolite to the digester didn't have any correlation to the digester performance (see Tables 7 and 87. However, the correlation coefficients, which were greater than zero, still showed that, actu- ally, there was still a correlation though it was a weak correlation.

Both the zeolite-immobilized and the BFA-immobilized digesters had the $K_{\mathrm{SX} 1}$ and $K_{\mathrm{SX} 2}$ value decreasing with the increase of the immobilization media number (see Tables 4 and 5). This decrease meant that cells/microbe could easily attach because $K_{\mathrm{S}}$ is the parameter representing the affinity of microbes to the solid substrate [34. A large $K_{\mathrm{S}}$ usually indicates a low affinity and vice versa for a small $K_{\mathrm{S}}$ [34]. Because of the lower value of $K_{\mathrm{SX} 1}$ and $K_{\mathrm{SX} 2}$, the cell/microbe preferred the BFA to the natural zeolite for the attachment. However, the cell/microbe attached to the solid substrate had been found to grow at a much 


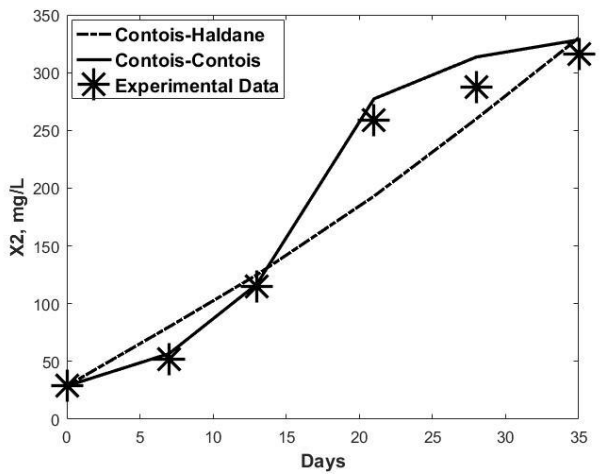

(a) Zeolite $-1 / 4$

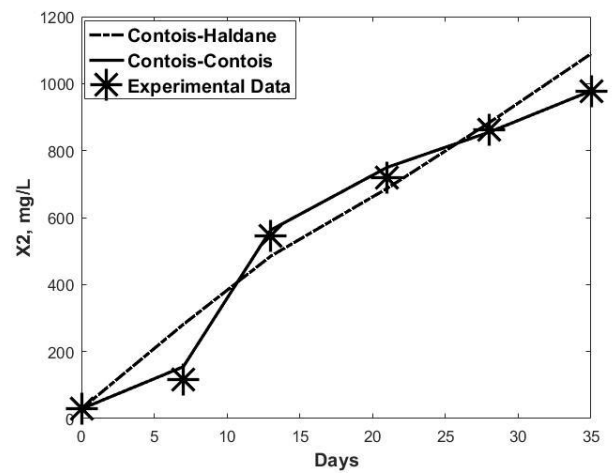

(c) Zeolite $-3 / 4$

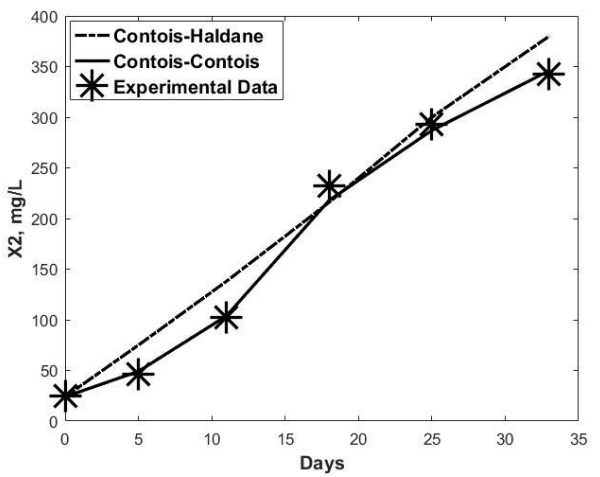

(e) BFA $-1 / 2$

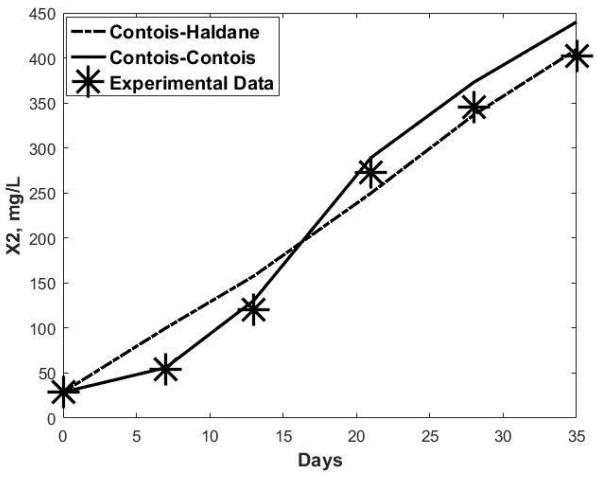

(b) Zeolite $-1 / 2$

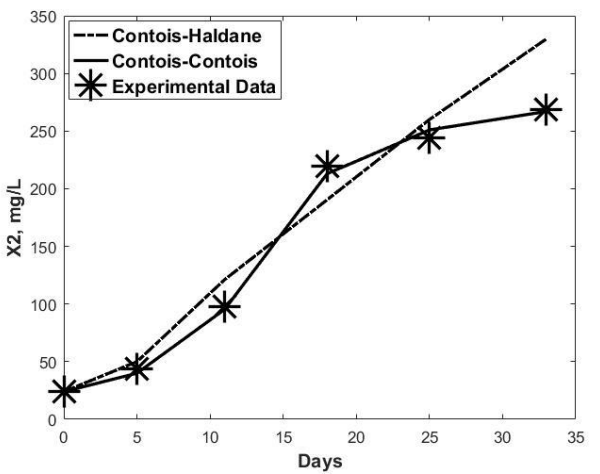

(d) BFA $-1 / 4$

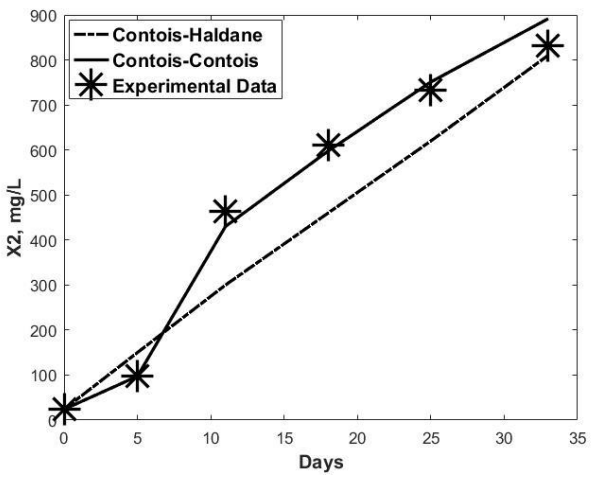

(f) $\mathrm{BFA}-3 / 4$

FiguRE 6. MATLAB calculation result for methanogenic cell (X2) inside the digester using natural zeolite and BFA as the immobilization media.

slower rate than the cell/microbe that was unattached due to its lack of a direct access to food [35. When more cell/microbes attach to the solid substrate, the overall growth rate of the cell is slower. Thus, the growth rate of the acidogenic and methanogenic cell was better when the digester used the natural zeolite as the immobilization media, since the number of the cells/microbes attached to the zeolite was quite low. It was revealed by the value of $\mu_{\mathrm{m} 1}$ and $\mu_{\mathrm{m} 2}$, which was greater when using the natural zeolite inside the digester (see Tables 4 and 5). The values of $Y_{\mathrm{X} 1 / \mathrm{COD}}$ and $Y_{\mathrm{X} 2 / \mathrm{VFA}}$ were also greater when using the natural zeolite inside the digester due to the ability of the cell/microbe to gain the food (in form of the sCOD and VFA).

Other kinetic constants dealing with the aforementioned explanation were $k_{\mathrm{d} 1}$ and $k_{\mathrm{d} 2}$ (see Tables 4 and 57. The more immobilization media added, the greater the value of both variables. This meant that the addition of more immobilization media caused more cells/microbes to attach on it, leading to more cells/microbes dying afterwards due to a lack of food. This result stood in line with the previous work by Wang et al. [35].

As the consequence of a better growth of the cell/microbe by using the zeolite, the rate of methane 


\begin{tabular}{lcc}
\hline Constants & $\begin{array}{c}\text { Correlation } \\
\text { coefficient }(r)\end{array}$ & Indication \\
\hline Nat. zeolite as the immobilization med. \\
\hline$\mu_{\mathrm{m} 1}$ & 0.617 & No correlation \\
$\mu_{\mathrm{m} 2}$ & -0.046 & No correlation \\
$K_{\mathrm{SX} 1}$ & -0.899 & No correlation \\
$K_{\mathrm{SX} 2}$ & -0.935 & No correlation \\
\hline$Y_{\mathrm{X} 1 / \mathrm{COD}}$ & 0.851 & No correlation \\
$Y_{\mathrm{X} 2 / \mathrm{VFA}}$ & 0.732 & No correlation \\
$Y_{\mathrm{CH} 4 / \mathrm{X} 2}$ & 0.266 & No correlation \\
$Y_{\mathrm{VFA} / \mathrm{X} 1}$ & -0.447 & No correlation \\
\hline$k_{\mathrm{d} 1}$ & 0.885 & No correlation \\
$c_{1}$ & 0 & No correlation \\
$k_{\mathrm{d} 2}$ & 0.746 & No correlation \\
$c_{2}$ & 0 & No correlation \\
\hline
\end{tabular}

TABlE 7. Pearson correlation coefficient of kinetics constants of Contois-Contois scenario (second scenario) for natural zeolite as the immobilization media.

production was more stable in the zeolite-immobilized digester. The yield of methane produced per the methanogenic cell increase $\left(Y_{\mathrm{CH} 4 / \mathrm{X} 2}\right)$ was still greater though the methanogenic cell growth rate was also greater in the zeolite-immobilized digester.

For the order of the death-rate constant, according to Shuler and Kargi 9], the order for the cell concentration of the death rate equation was first order. This work tried to prove the validity of this order. The numerical calculation using MATLAB showed that the death rate of the acidogenic and methanogenic cell had order's value almost identical to first order. Thus, its validity was verified.

\section{Conclusions}

The addition of the zeolite and the BFA as the immobilization media in the anaerobic digester showed different digester's behaviour. In the BFA-immobilized digester, the hydrolysis seemed to take part at the beginning of the operation, therefore, causing the sCOD and $C_{\mathrm{VFA}}$ to increase at first. In contrast, the zeolite-immobilized digester had only acidogenesis and methanogenesis as the limiting processes, causing the the sCOD and $C_{\mathrm{VFA}}$ to decrease from the start. Besides, the methane purity and the cumulative methane volume of the zeolite-immobilized digester were greater than those of the BFA-immobilized digester. Kinetically, the anaerobic leachate digestion using the natural zeolite and the BFA as the immobilization media followed the Contois model both for the acidogenesis and for the methanogenesis step. A statistical analysis showed that a higher ratio of the immobilization media did positively affect some kinetics parameters. It indicated that the natural zeolite was plausible to be further studied as the potential immobilization media for anaerobic digestion purposes.

\begin{tabular}{|c|c|c|}
\hline Constants & $\begin{array}{c}\text { Correlation } \\
\text { coefficient }(r)\end{array}$ & Indication \\
\hline \multicolumn{3}{|c|}{ BFA as the immobilization media } \\
\hline$\mu_{\mathrm{m} 1}$ & 0.944 & No correlation \\
\hline$\mu_{\mathrm{m} 2}$ & 0.96 & Correlated \\
\hline$K_{\mathrm{SX} 1}$ & -0.868 & No correlation \\
\hline$K_{\mathrm{SX} 2}$ & -0.205 & No correlation \\
\hline$Y_{\mathrm{X} 1 / \mathrm{COD}}$ & 0.831 & No correlation \\
\hline$Y_{\mathrm{X} 2 / \mathrm{VFA}}$ & 0.865 & No correlation \\
\hline$Y_{\mathrm{CH} 4 / \mathrm{X} 2}$ & -0.375 & No correlation \\
\hline$Y_{\mathrm{VFA} / \mathrm{X} 1}$ & -0.913 & No correlation \\
\hline$k_{\mathrm{d} 1}$ & 0.871 & No correlation \\
\hline$c_{1}$ & 0.833 & No correlation \\
\hline$k_{\mathrm{d} 2}$ & 0.119 & No correlation \\
\hline$c_{2}$ & 0.834 & No correlation \\
\hline
\end{tabular}

TABLE 8. Pearson correlation coefficient of kinetics constants of Contois-Contois scenario (second scenario) for BFA as the immobilization media.

\section{ACKNOWLEDGEMENTS}

The study was conducted under the CLEAN Project financially supported by USAID PEER-Science Research Grant [NAS Sub-Grant Award Letter Agreement Number 2000004934 and Sponsor Grant Award Number AID-OAAA-11-00012]. The authors also expressed the highest appreciation to the Office of Civil Work and Energy/Mineral Resources of Yogyakarta and the bureau of Waste Treatment, Infrastructure, and Municipal Water Supply of the Government of D.I. Yogyakarta Province.

\section{LIST OF SYMBOLS}

$\mu_{\mathrm{m} 1}$ maximum specific growth rate of acidogenic cell $\left(\right.$ day $\left.^{-1}\right)$

$\mu_{\mathrm{m} 2}$ maximum specific growth rate of methanogenic cell $\left(\right.$ day $\left.^{-1}\right)$

$K_{\mathrm{SX} 1}$ half-saturation constant associated with sCOD ( $\mathrm{mg} \mathrm{sCOD} / \mathrm{mg}$ acidogenic cell)

$K_{\mathrm{SX} 2}$ half-saturation constant associated with VFA (mg VFA/mg methanogenic cell)

$Y_{\mathrm{X} 1 / \mathrm{COD}}$ yield of cell formation per mg sCOD reduction (mg acidogenic cell $/ \mathrm{mg} \mathrm{sCOD)}$

$Y_{\mathrm{X} 2 / \mathrm{VFA}}$ yield of cell formation per mg VFA reduction (mg methanogenic cell/mg VFA)

$Y_{\mathrm{CH} 4 / \mathrm{X} 2}$ yield of $\mathrm{CH}_{4}$ formation per mg methanogenic cell/L increase $\left(\left(\mathrm{mg} \mathrm{CH}_{4} / \mathrm{L}\right) /(\mathrm{mg}\right.$ methanogenic cell $\left./ \mathrm{L})\right)$

$Y_{\mathrm{VFA} / \mathrm{X} 1}$ yield of VFA formation per $\mathrm{mg}$ acidogenic cell (mg VFA/mg acidogenic cell)

$K_{\mathrm{I}}$ inhibition constant associated with VFA (mg VFA/L)

$k_{\mathrm{d} 1}$ death rate constant of acidogenic cell

$k_{\mathrm{d} 2}$ death rate constant of methanogenic cell

$c_{1}$ order of acidogenic cell death rate equation

$c_{2}$ order of methanogenic cell death rate equation

\section{REFERENCES}

[1] El-Salam, M.M.A., Abu-Zuid, G.I., 2015. Impact of landfill leachate on the groundwater quality: A case 
study in Egypt. Journal of Advanced Research, 6 (4), 579-586. DOI:10.1016/j.jare.2014.02.003

[2] Kettunen, R.H., Hoilijoki, T.H., Rintala, J.A., 2009. Anaerobic and sequential anaerobic-aerobic treatments of municipal landfill leachate at low temperatures, Bioresource Technol. 58, 40-41.

[3] Silva, A.C., Dezotti, M., Sant'Anna Jr, G.L., 2004. Treatment and detoxification of a sanitary landfill leachate. Chemosphere, 55 (2), pp. 207-214. DOI:10.1016/j.chemosphere.2003.10.013

[4] Im, J.H., Woo, H.J. Choi, M.W., Han, K.B., Kim, C.W., 2001. Simultaneous organic and nitrogen removal from municipal landfill leachate using an anaerobic-aerobic system. Water Res. 35, 2403-2410. DOI:10.1016/S0043-1354(00)00519-4

[5] Wiratni, W. and Subandiyono, 2009. Enhancement of Methane Formation in Biogas Production by Addition of Landfill Leachate. Proceeding of Regional Conference on Chemical Engineering, De La Salle University, Manila.

[6] Santosa, N.B., 2014. Pemanfaatan LNG sebagai Sumber Energi di Indonesia. Jurnal Rekayasa Proses. 8(1), 33-39.

[7] Deendarlianto, D., Wiratni, W., Tontowi, A., Indarto, I., \& Iriawan, A. 2015. The Implementation of a Developed Microbubble Generator on the Aerobic Wastewater Treatment. International Journal Of Technology. 6(6), 924-930. DOI:10.14716/ijtech.v6i6.1696

[8] Budhijanto, W., Deendarlianto, D., Kristiyani, H., \& Satriawan, D., 2015. Enhancement of Aerobic Wastewater Treatment by the Application of Attached Growth Microorganisms and Microbubble Generator. International Journal of Technology. 6(7), 1101-1109. DOI:10.14716/ijtech.v6i7.1240

[9] Shuler, M., Kargi, F., 2002. Bioprocess Engineering Basic Concepts, second ed. Prentice Hall, New Jersey.

[10] Mshandete, A.M., Björnsson, L., Kivais, A.K., Rubindamayugi, M.S.T., Mattiasson, B., 2008. Performance of biofilm carriers in anaerobic digestion of sisal leaf waste leachate,"Electronic Journal of Biotechnology 2008; 11 (1), pp.1-9. DOI:10.2225/vol11-issue1-fulltext-7

[11] Kourkoutas, Y., Xolias, V., Kallis, M. Bezirtzoglou, E., and Kanellaki, M., 2005. Lactobacillus casei cell immobilization on fruit pieces for probiotic additive, fermented milk and lactic acid production. Process Biochem. 40, 411-416.

[12] Wirawan, S.K., Sudibyo, H., Setiaji, M.F., Warmada, I.W., Wahyuni, E.T., 2015. Development of natural zeolites adsorbent: chemical analysis and preliminary TPD adsorption study. Journal of Engineering Science and Technology. Special Issue 4 on SOMCHE 2014 \& RSCE 2014 Conference, 87-95.

[13] Rainey, T.J., 2009. A study of the permeability and compressibility properties of bagasse pulp. Brisbane, Australia: Queensland University of Technology.

[14] Mathew, S., Abraham, T.E., 2005. Studies on the production of feruloyl esterase from cereal brans and sugar cane bagasse by microbial fermentation. Enzyme Microb. Tech. 36 (4), 565-570. DOI:10.1016/j.enzmictec.2004.12.003
[15] Carvalho, W., Santos, J.C., Canilha, L., Silva, S.S., Perego, P., Converti, A., 2005. Xylitol production from sugarcane bagasse hydrolysate: metabolic behaviour of Candida guilliermondii cells entrapped in Caalginate.

Biochem. Eng. J. 25 (1), 25-31.

DOI:10.1016/j.bej.2005.03.006

[16] Santos, J.C., Carvalho, W., Silva, S.S., Converti, A., 2003. Xylitol production from sugarcane bagasse hydrolyzate in fluidized bed reactor. Effect of air flowrate. Biotechnology Progress. 19 (4), 1210-1215. DOI:10.1021/bp034042d

[17] Sene, L., Converti, A., Felipe, M.G.A., Zilli, M., 2002. Sugarcane bagasse as alternative packing material for biofiltration of benzene polluted gaseous streams: A preliminary study. Bioresource Technol. 83 (2), 153-157. DOI:10.1016/S0960-8524(01)00192-4

[18] Nelson, M., Sidhu, H. Reducing the emission of pollutants in food processing wastewaters., 2007. Chem. Eng. Proc. Process Intensification. 46 (5), 429-436. DOI:10.1016/j.cep.2006.04.012

[19] Hussain, A., Dubey, S. K., Kumar, V., 2015. Kinetic study for aerobic treatment of phenolic wastewater. Water Resources and Industry. 11, 81-90. DOI:10.1016/j.wri.2015.05.002

[20] Boothe, D.D.H., Smith, M.C., Gattie, D.K., Das, K.C., 2001. Characterization of microbial populations in landfill leachate and bulk samples during aerobic bioreduction. Adv. Environ. Res. 5, 285-294. DOI:10.1016/S1093-0191(00)00063-0

[21] American Public Health Association (APHA), 2005. Standard Methods for the Examination of Water and Wastewater, twentieth ed. American Public Health Association, New York.

[22] Fabregas, J., Herrero, C., Cabezas, B., Abalde, J., 1986. Biomass production and biochemical composition in mass cultures of the marine microalga Isochrysis galbana Parke at varying nutrient concentrations Aquaculture. 53(2), 101-113. DOI:10.1016/0044-8486(86)90280-2

[23] Wirth, R., Kovács, E., Maróti, G., Bagi, Z., Rákhely, G., Kovács, K.L., 2012. Characterization of a biogas-producing microbial community by short-read next generation DNA sequencing. Biotechnol. Biofuels. 5, 41. DOI:10.1186/1754-6834-5-41

[24] American Public Health Association (APHA), 1984. Compendium of Methods for the Microbiological Examination of Foods, second ed. American Public Health Association, Washington, D.C.

[25] Walker, M. Zhang, Y., Heaven, S., and Banks, C., 2009. Potential Errors in the Quantitative Evaluation of Biogas Production in Anaerobic Digestion Processes. Bioresource Technol. 100, 6339-6346. DOI:10.1016/j.biortech.2009.07.018

[26] Budiyono, Syaichurrozi, I., Sumardiono, S., 2014. Effect of Total Solid Content to Biogas Production Rate from Vinasse. IJE Transactions B: Applications, 27 (2), $177-184$ 
[27] Tomei, L., Altamura, S., Bartholomew, L., Bisbocci, M., Bailey, C., Bosserman, M., Cellucci, A., Forte, E., Incitti, I., Orsatti, L., Koch, U., 2004. Characterization of the inhibition of hepatitis $\mathrm{C}$ virus RNA replication by nonnucleosides. J. Virol. 78(2), 938-946. DOI:10.1128/JVI.78.2.938-946.2004

[28] Grady Jr., C.P.L., Daigger, G.T., Love, N.G., Filipe, C.D.M., 2011. Biological Wastewater Treatment. CRC Press Taylor \& Francis Group: Boca Raton, Florida, p. 296.

[29] Geed, S.R., Kureel, M.K., Giri, B.S., Singh, R.S., Rai, B.N., 2017. Performance evaluation of Malathion biodegradation in batch and continuous packed bed bioreactor (PBBR). Bioresour. Technol. 227, 56-65. DOI:10.1016/j.biortech.2016.12.020

[30] Fedailaine, M., Moussi, K., Khitous, M., Abada, S., Saber, M., Tirichine, N., 2015. Modeling of the anaerobic digestion of organic waste for biogas production. Procedia Comput. Sci. 52, $730-737$. DOI:10.1016/j.procs.2015.05.086

[31] Stucki M., Jungbluth N., Leuenberger M., Life cycle assessment of biogas production from different substrates, Final report, Federal Department of Environment, Bern (2011 Dec), Transport, Energy and Communications, Federal Office of Energy.

[32] Achinas, S., Achinas, V., Euverink, G.J.W., 2017. Technological Overview of Biogas Production from Biowaste. Engineering. 3 (3), 299-307. DOI:10.1016/J.ENG.2017.03.002

[33] Chiu, S.F., Chiu, J.Y., Kuo, W.C., 2013. Biological stoichiometric analysis of nutrition and ammonia toxicity in thermophilic anaerobic codigestion of organic substrates under different organic loading rates. Renew. Energ. 57, 323-329. DOI:10.1016/j.renene.2013.01.054

[34] Liu, Y., 2006. A simple thermodynamic approach for derivation of a general Monod equation for microbial growth. Biochem. Eng. J. 31, 102-105. DOI:10.1016/j.bej.2006.05.022

[35] Wang, Z.W., Hamilton-Brehm, S.D., Lochner, A., Elkins, J.G., Morrell-Falvey, J.L., 2011. Mathematical modeling of hydrolysate diffusion and utilization in cellulolytic biofilms of the extreme thermophile Caldicellulosiruptor obsidiansis. Bioresour.Technol. 102, 3155-3162. DOI:10.1016/j.biortech.2010.10.104 